\title{
In-situ stress amplification due to geological factors in tunnels: The case of Pajares tunnels, Spain
}

\author{
T. Hijazo a , L.I. González de Vallejo a,b,* \\ a Prospección y Geotecnia, Spain \\ ${ }^{b}$ Geological Engineering, Facultad de CC. Geológicas, Universidad Complutense de Madrid, Spain
}

Keywords:

In-situ stress

Tectonic stress

Structural stress

Stress amplification

Tunnel geology

Support design

\begin{abstract}
A B S T R A C T
Geological and geomechanical anisotropies can significantly increase the magnitude of in-situ stress in a rock mass excavated for tunnelling purposes. Four tunnels for the new high-speed railway lines in Pajares in the Cantabrian Mountains, N. Spain, were analysed and significant deformations was found to have occurred in forty specific zones of these tunnels during excavation, requiring much more support than envisaged before construction. Local factors influencing in-situ stress have been identified in these zones of the tunnels, related to geological structures of high compressive tectonic stress regimes including thrust faults, folds with steep flank dip, or with geomechanical anisotropies in contact zones between rock formations of different strengths. A methodological procedure was applied to four tunnels to assess the influence of the geological anisotropies on the insitu stress magnitudes. This procedure is based on the analysis of tunnel defonmations and the support pressure needed to stabilise the excavations affected by geological anisotropies.

The increase of in-situ stress due to local factors is expressed by the Stress Amplification Factor (SAF) defined by the ratio between the $\mathrm{K}\left(\sigma_{\mathrm{H}} / \sigma_{\mathrm{V}}\right)_{\text {local }}$ value estimated in a particular rock mass tunnel zone and the mean $\mathrm{K}\left(\sigma_{\mathrm{H}} / \sigma_{\mathrm{V}}\right)_{\text {regional }}$ value representative of the whole rock mass tunnel. $\mathrm{K}_{\text {regional }}$ was estimated from hydrofracture tests and from the TSI index. Klocal was calculated from the back analysis of the support pressure required to stabilise the deformed tunnel zones. SAFvalues for the forty specific tunnel zones ranged from 1.1 to 2.5. This significant increase in the magnitude of in-situ stress emphasises the influence of geological and geomechanical anisotropies in tunnel stability and support design. The results provide a quantitative approach for assessing structural stresses in rock masses for tunnelling excavations.
\end{abstract}

\section{Introduction}

The importance of the in-situ stress on the stability of underground excavations is widely recognised. When anisotropic or high in-situ stress are present, failure and plastification phenomena such as squeezing or rockburst may occur, so that it is essential to know the magnitude and direction of in-situ stress for any underground project (Hoek and Marinos, 2009). However, this important consideration is often ignored and many tunnels are still designed without insitu stress measurements. Even when in-situ tests are carried out to assess the magnitude and direction of the state of stress, mean values are usually assigned for the whole rock mass affected by the tunnel, without considering the influence of geological anisotropies on the whole tunnel profile. The importance of these anisotropies has often been underestimated and very little research into this subject is available.
This paper focuses on the influence of geological anisotropies on the magnitude of in-situ stress in tunnel projects. Based on practical experience of long-term stability problems in tunnels and underground mines located in the study area of Pajares Mountains (N. Spain), where significant deformations linked to faults and other geological anisotropies has been detected, a study was carried out of the new high speed railway tunnels recently constructed in these mountains.

\section{Geological influencing factors in the magnitude of in-situ stress}

Conceptual models to explain the typology and origin of stresses in the upper and elastic lithosphere have been developed by Bott and Kusznir (1984) and Zoback et al. (1989). Both models consider two categories of forces: the first category causes tectonic stress and the second causes local stress on a lithospheric scale. Based on these models, a new in-situ stress classification and terminology was proposed by Zang and Stephansson (2010) which has been adopted in this paper.

The main factors affecting stress magnitude on a continental scale are the thickness, composition and age of the crust, crustal heterogeneities and the geothermal gradient. The stress direction is influenced 
mainly by plate geometry and the distribution of the different plate boundaries (Zoback et al., 1989). These factors generate continental range stresses and their radius of influence can be hundreds or thousands of kilometres. Within the same region, however, the stress magnitude and direction may vary considerably due to what are known as local factors or stress anisotropies. These types of in-situ stress of tectonic origin are called tectonic stress, and are responsible for the state of stress in the upper part of the lithosphere.

In rock mechanics there is a problem of scale, given that the stress studies carried out by geologists or geophysicists are on a large or continental scale, while engineering projects usually range from hundred to thousand of metres and are rarely more than $1500 \mathrm{~m}$ in depth, and so local stress variations are too small to be represented on a global scale (Hoek and Marinos, 2009). The main factors influencing stress magnitude on an engineering scale may include geological and structural anisotropies, sedimentary loads, relief effects, glacial rebound, loads produced by submarine elevations or the convexity of the oceanic lithosphere and rock composition and geomechanical behaviour.

Rock masses are anisotropic and heterogeneous and are often fractured, with non-homogeneous stress distribution. Many studies have shown that both lithological heterogeneities and the geological structure influence stress magnitude (Goodman, 1980). Faults are one of the main tectonic structures which can influence stress magnitude and direction (Zoback et al., 1980). These types of stresses are called structural stress (Zang and Stephansson, 2010).

Joints, fractures and faults effectively reduce the stress needed for fragile rock failure to occur (Griggs et al., 1960), as can be also observed from in-situ stress measurements. In many cases, the increase or decrease of stress magnitude is due to the local influence of discontinuities, faults, dikes, heterogeneities, intrusive bodies and folds, with variations of up to tens of MPa in faults or shear zones (Stephansson, 1993).

Lithological heterogeneities and structural anisotropies may also lead to stress concentrations. In contact zones between materials of different strengths, variations have been observed in horizontal stress magnitude with depth (Evans et al., 1989 and Cornet and Burlet, 1992). Similarly, in rock masses with geological anisotropies and high Poisson ratios, higher $K$ values have been recorded than the regional $K$ value (Gunzburger and Cornet, 2007). These stress concentrations are also structural stress.

The sedimentary loads applied on an elastic lithosphere cause important stress deviation and lead to flexural stresses which may be of several hundred MPa, and can disturb the regional stress field at distances of up to $1000 \mathrm{~km}$. On the passive continental boundaries these loads are the main stress source.

Very high relief and its isostatic compensation at depth may generate important stresses. In general terms, thickening of the crust or thinning of the lithosphere produces negative density anomalies and therefore tensile stresses, while crustal thinning or lithospheric thickening produce positive density anomalies and so generate compressive stresses.

Relief can also exert considerable influence on the stress in areas nearest the surface and the resulting in-situ stress is called gravity stress. A section through a slope with stress trajectories shows that the direction of the major principal stress is aligned roughly parallel to the ground surface near the slope and approaches the vertical with increasing distance from it. Consider a tunnel located in a steep-sided valley where the regional horizontal in-situ stress is estimated to be twice the vertical stress. The horizontal stress at right angles to the valley axis may vary from one half to twice the vertical stress. The stress parallel to the valley may vary from a minimum value equal to the vertical stress to a maximum value of three times the vertical stress (Hoek and Marinos, 2009).

Other factors influencing the state of stress are erosion and denudation processes which cause high horizontal stress on areas near the surface (Voight, 1966b).
The geological history and behavioural evolution of rocks in relation to stress fields applied in the long term may significantly influence the state of stress. The maximum stress reached depends on the time interval between preloading and reloading as well as on the duration of the load application during preloading (Lavrov, 2003). These processes have been considered in the Kaiser effect (Montoto and Hardy, 1991; Villaescusa et al., 2003; Lehtonen et al., 2012). These residual stresses remain stored or accumulated even when external forces, such as tectonic forces, are no longer acting.

Rocks subjected to constant stress may display viscoelastic behaviour, with stress released over time in the most ductile areas of the crust. Savage et al. (1992) have shown that the minimum horizontal stress $\left(\sigma_{\mathrm{h}}\right)$ also depends on time. Over long time periods, the gravitational component of the horizontal stress becomes hydrostatic and the strain rate-dependent component becomes constant.

Induced stresses is caused by tunnelling excavations that redistribute and modify the in-situ stress around the tunnel section; this type of stress is called perturbed in-situ stress in Zang and Stephansson (2010).

\section{Estimating in-situ stress magnitude}

In-situ tests to determine the magnitude and direction of in-situ stress have been described by Cornet (2003) and Hudson and Harrison (2005). Empirical relationships between $\mathrm{K}\left(\sigma_{\mathrm{H}} / \sigma_{v}\right)$ and depth or lithology have been proposed by Coates and Grant (1966), Hast (1967), Bulin (1971) and Hoek and Brown (1980), among others. Using the World Stress Map (Heidbach et al., 2008) and other sources, González de Vallejo and Hijazo (2008) plotted a large dataset of stress magnitudes versus depth on a global scale (Fig. 1). This figure also shows the minimum and maximum envelope lines according to different authors. The maximum envelope lines are generally similar, with less data scatter for depths greater than $1000 \mathrm{~m}$, with $\mathrm{K}$ tending towards 1 with depth. The minimum envelope lines show greater discrepancies for depths below $500 \mathrm{~m}$. These results show that at typical depths for most underground excavations, K-depth relationships cannot be used in practice.

Alternative empirical relationships have been proposed by González de Vallejo and Hijazo (2008) using the TSI index to account for tectonic stress. This index considers tectonic and geological parameters and elastic properties of the rocks (Eq. (1)). The relationships between $\mathrm{K}$

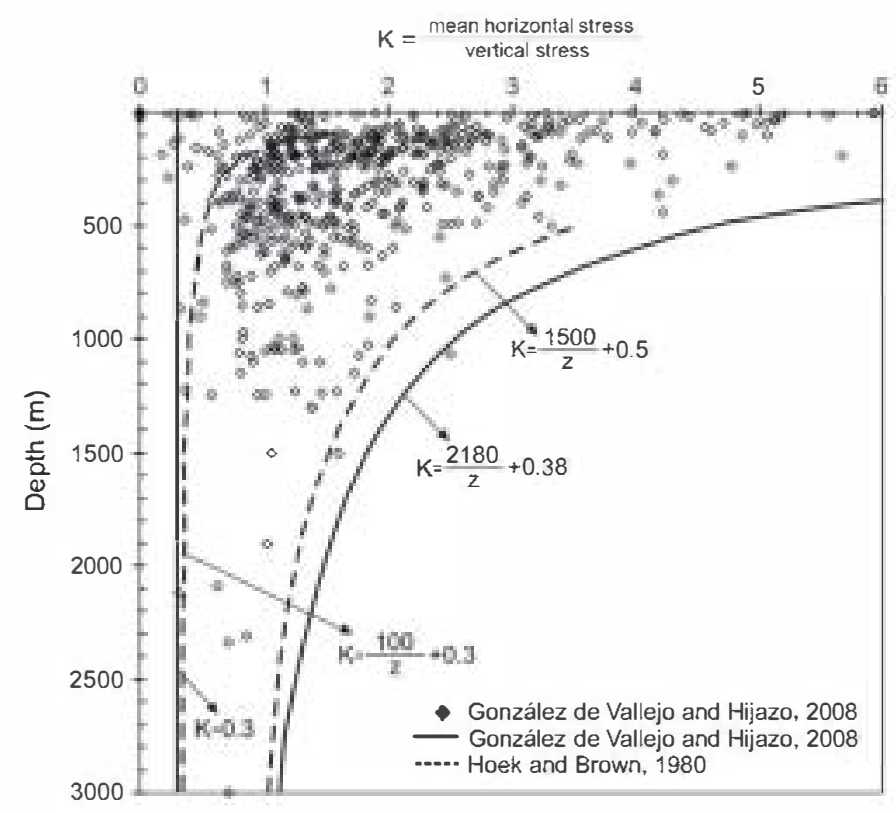

Fig. 1. K-depth relationships based on global data, compiled by González de Vallejo and Hijazo (2008). $K$ values have been calculated as defined by Hoek and Brown (1980) as $\mathbf{K}=\left(\sigma_{\mathbf{H}}+\sigma_{h} / 2\right) / \sigma_{v}$ to compare the envelopes lines. 
and the TSI were derived from an extensive worldwide database corresponding to different zones in which several in-situ stress measurements were taken to give a mean $\mathrm{K}$ value (Hijazo, 2009). Eqs. (2) and (3) show K-TSI relationships obtained from global data as a function of the age of the main tectonic orogeny affecting the rock mass. Eqs. (4) and (5) show regional K-TSI relationships for Spain (Fig. 2):

$\mathrm{TSI}=\log [(\mathrm{T} / \mathrm{H} \cdot \mathbf{E})]$

where $\mathrm{T}=$ age of the first orogenic cycle or main folding period affecting the rock mass (years) (Hercynian $=300 \mathrm{Ma}$, Alpine $=12 \mathrm{Ma}$ and Caledonian $=600 \mathrm{Ma}) ; \mathrm{E}=$ elastic modulus of the intact rock $(\mathrm{GPa})$; $\mathrm{H}$ : maximum overburden thickness throughout its geological history (metres).

$K_{\text {global }}=-1.93 \cdot \mathrm{TSI}+8.38$ for Hercynian rocks

$K_{\text {global }}=-2.09 \cdot \mathrm{TSI}+6.15$ for Alpine rocks

$\mathrm{K}_{\text {regional }}=-2.27 \cdot \mathrm{TSI}+9.51$ for Hercynian rocks

$K_{\text {regienal }}=-2.45 \cdot \mathrm{TSI}+7.27$ for Alpine rocks.

\section{Methodology}

To account for local factors (structural and perturbed in-situ stresses) influencing the in-situ stress in a tunnel excavation, the followingmethodology has been developed (Fig. 3):

- From the hydrofracture test and TSI index (K-TSI relationships) a representative value of $K_{\text {regional }}$ is assigned for an undisturbed rock mass not affected by perturbed in-situ and structural stress (Fig. 3: $1 \mathrm{a}, 1 \mathrm{~b}$ and $1 \mathrm{c}$ ).

- $\sigma_{\mathrm{H}}$ can be obtained from $\mathrm{K}_{\text {regional }}$ assuming this is the maximum horizontal stress due to tectonic stress and corresponds to $\sigma_{\text {Hregional }}$ (Fig. 3: 1d).

- Before tunnel excavation the support is designed and the support pressure $\left(\mathrm{P}_{0}\right)$ is calculated for different tunnel sections. A mean insitu stress value equivalent to $\mathrm{K}_{\text {regional }}$ is usually adopted for support calculations (Fig. 3: 2a).

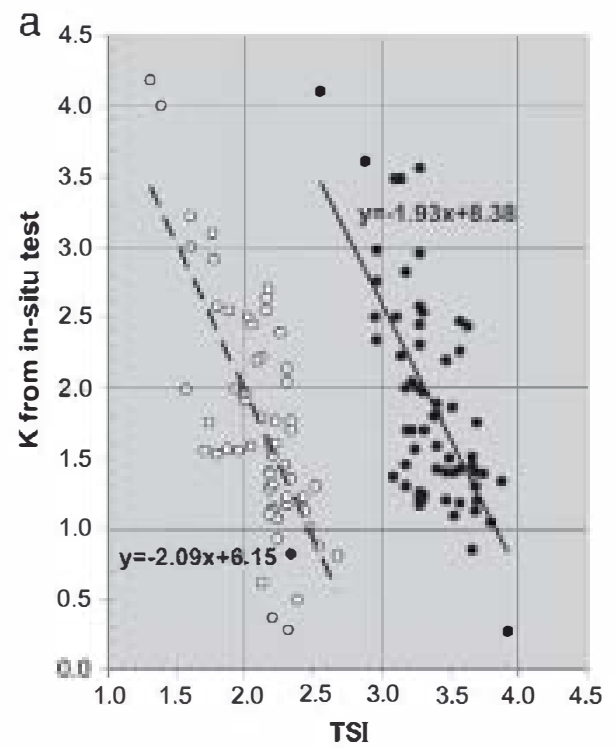

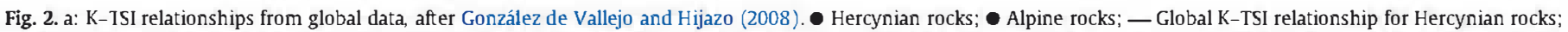

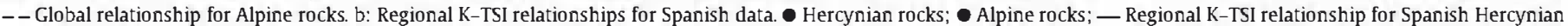
rocks; - - Regional K-TSI relationship for Spanish Alpine rocks.

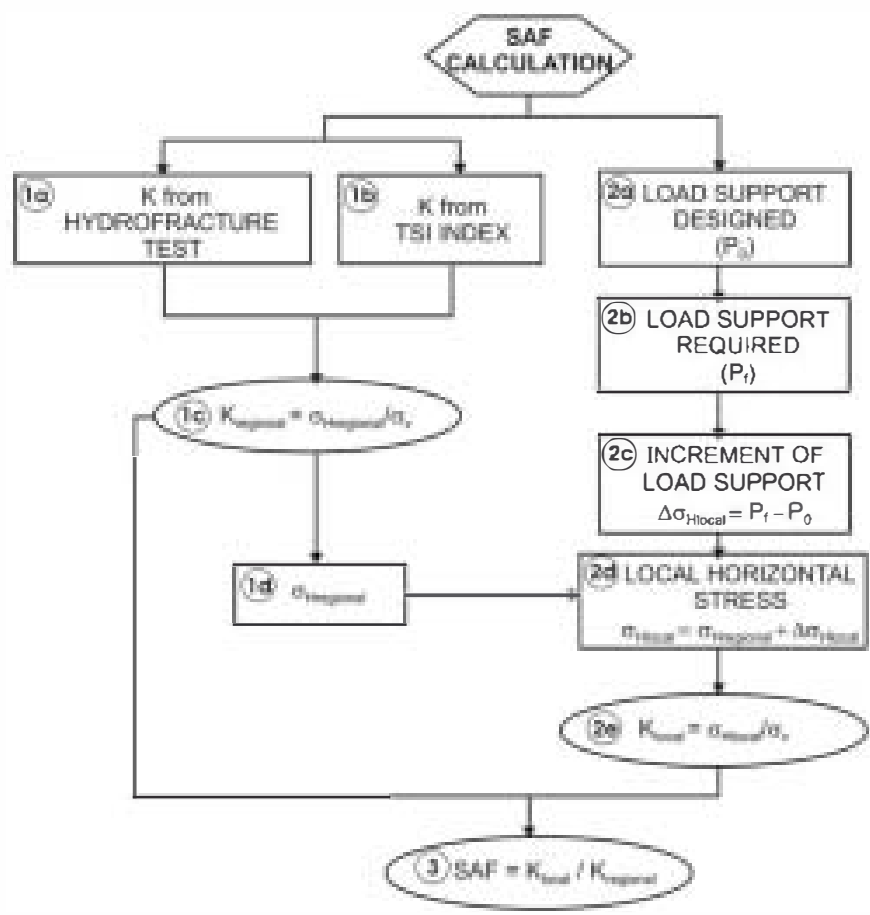

Fig. 3. Estimating the Stress Amplification Factor (SAF) in the Pajares tunnels.

- If some tunnel zones deformmore than expected during excavation, the support has to be modified by increasing the support pressure $\left(\mathrm{P}_{\mathrm{f}}\right)$ as required to stabilise the rock mass deformations (Fig. 3: 2b).

- Geological and geomechanical surveys can identify geological structures and rock mass anisotropies associated with the tunnel zones affected by significant deformations. In these cases the increment of the support pressure $\left(\mathrm{P}_{\mathrm{f}}-\mathrm{P}_{\mathrm{o}}\right)$ can be attributed to the structural and perturbed in-situ stresses, where this increment is $\Delta \sigma_{\text {Hlocal }}=\mathrm{P}_{\mathrm{f}}-\mathrm{P}_{\mathrm{o}}$ (Fig. 3: 2c).

- In the tunnelzones with significant deformations the maximum horizontal stress is assumed to be equivalent to: $\sigma_{\text {Hlocal }}=\sigma_{\text {Hregional }}+$ $\Delta \sigma_{\text {Hlocal }}$. The sign in this equation is positive because only the tunnel zones where $\sigma_{\text {Hlocal }}$ is higher than the $\sigma_{\text {Hregional }}$ are considered (Fig. 3: 2d).

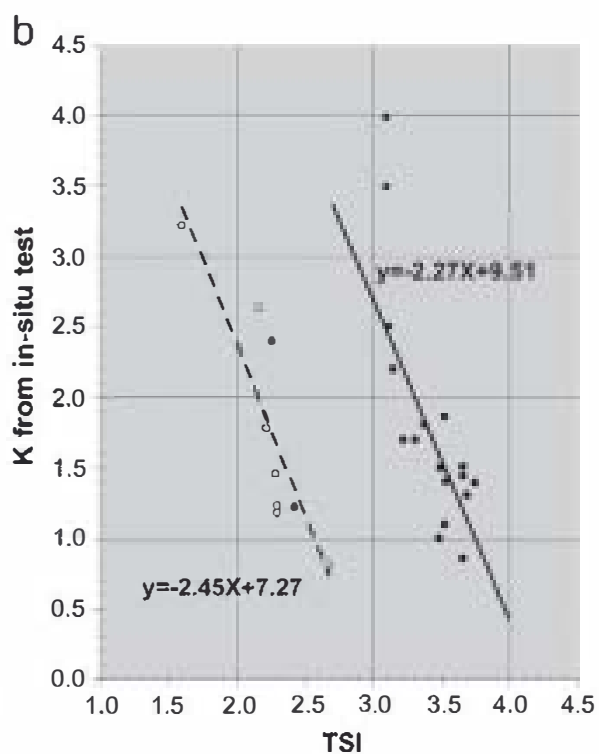


- In these tunnel zones the in-situ stresses are affected by structural and perturbed in-situ stresses and the new $\mathrm{K}$ values ( $\mathrm{K}_{\text {local }}$ ) can be obtained for each zones, where $\mathrm{K}_{\text {local }}=\sigma_{\text {Hlocal }} / \sigma_{v}$ (Fig. 3: 2e).

- $\mathrm{K}_{\text {local }} / \mathrm{K}_{\text {regional }}$ ratios are calculated to obtain the Stress Amplification Factor (SAF). This factor is related to the increment of the insitu stress due to structural and perturbed in-situ stresses (Fig. 3: 3).

\section{Application to Pajares tunnels}

The previously described methodology was applied to four tunnels which are part of a new high speed railway line in Cantabrian Mountains between León and Asturias, N. Spain (Fig. 4). Buen Suceso I, Peredilla, Nocedo and Alba tunnels were excavated by drill and blasting methods and supports were designed following the NATM. The tunnel sections and lengths range from 75 to $90 \mathrm{~m}^{2}$ and 391-684 $\mathrm{m}$ respectively, with a total length of $2177 \mathrm{~m}$. A comprehensive site investigation programme was carried out for preliminary studies, design and excavation purposes, including boreholes, hydrogeological and geophysical surveys and in-situ and laboratory tests (Míguez, 2009). Hydrofracture tests and geotechnical instrumentation, mainly convergences measurements and load cells, were installed during the tunnel excavation.

The rock masses affected by these tunnels are formed by Devonian and Carboniferous materials, predominantly limestones, dolomites, shales, sandstones, conglomerates and quartzites. The geological structure consists on folds and thrust faults (U.T.E. Ineco-Geoconsult, 2005). The geomechanical properties of the materials are summarised in Table 1. The geological cross section of the Buen Suceso I tunnel is shown in Fig. 5 as an example. lithology, rock mass classification and support measurements are also included in this figure.

The tunnels are located in a complex geological structure formed by heterogeneous materials. In-situ stresses in this region are usually moderate. Hydrofracture tests obtained a mean value of $K=1.5$ (Hullera Vasco-Leonesa, 1988). However, important deformations were observed in tunnels and mines located in this region, affecting the same type of materials and geological structures as in the tunnels analysed.

During the construction of the four tunnels significant deformations was measured in forty zones. An investigation into the relationships between these deformations and geological anisotropies was carried out. Geological and geomechanical surveys identified thrust faults, fold structures and contacts between rocks with significantly contrasting strength and deformability properties, related to the deformations (Fig. 5).To stabilise the excavations the support designed in the project had to be replaced by heavier supports (Fig. 5).
Table 1

Geomechanical properties of the materials of the tunnels analysed.

\begin{tabular}{lrlll}
\hline Lithologies & & $\begin{array}{l}\text { Unit weight } \\
\left(\mathrm{kN} / \mathrm{m}^{3}\right)\end{array}$ & $\begin{array}{l}\text { Uniaxial compressive } \\
\text { strength } \sigma_{\mathrm{c}}(\mathrm{MPa})\end{array}$ & $\begin{array}{l}\text { Elasticity } \\
\text { modulus E (GPa) }\end{array}$ \\
\hline Conglomerates & 1 & 27.9 & 12.0 & 13.0 \\
Shales & 2 & 26.5 & 10.4 & 16.6 \\
& 3 & 26.8 & 12.3 & 12.3 \\
Sandstones & 4 & 28.0 & 19.3 & 7.5 \\
& 5 & 26.8 & 17.1 & 32.0 \\
& 6 & 26.8 & 53.0 & 17.1 \\
& 7 & 27.4 & 53.4 & 37.7 \\
Limestones & 8 & 25.5 & 15.5 & 17.2 \\
& 9 & 27.2 & 34.5 & 31.8 \\
& 10 & 27.4 & 37.5 & 35.4 \\
& 11 & 27.0 & 53.7 & 52.9 \\
& 12 & 27.0 & 30.0 & 40.6 \\
& 13 & 27.7 & 38.5 & 50.4 \\
\hline
\end{tabular}

a $1:$ Fm. Pastora, 2: Fm. Candanedo, $3:$ Fm. Huergas, $4:$ Fm. Fueyo, $5:$ Fm. Olleros, 6 : Fm Huergas, 7: Fm. Nocedo, 8: Fm. Fueyo, 9: Fm Ermita, 10: Fm Olleros, 11: Fm. Portilla 12: Fm Alba, 13: Fm. Barcaliente. Fm: Formation. The data refer to mean values.

Based on a back analysis of the rock mass deformations and the support pressure needed to stabilise the tunnel sections, SAF values were estimated in the forty tunnel zones following the methodological procedure described in Section 4. An example of SAF calculation for one of the tunnel zones is shown below.

One of the zones affected by deformations in the Buen Suceso I tunnel is $29 \mathrm{~m}$ long (Fig. 5, zone no. 6). The geological profile is shown in Fig. 5. The materials are sandstones and shales (Table 1, lithology no. 12). The overburden thickness in this tunnel zone ranges from 73 to $76.5 \mathrm{~m}$.

Hydrofracture tests carried out in this area show $\mathrm{K}$ values between 1.39 and 1.80 (U.T.E. Geoconsult-Ineco-CGS, 2003). The TSI index was also calculated, obtaining a mean $\mathrm{K}$ value of 1.27 , which was assigned to Kregional.

$\sigma_{\text {Hregional }}$ was estimated as follows:

$\sigma_{\text {Hregienal }}=K_{\text {regional }} \cdot \sigma_{\mathrm{v}}=1.27 \cdot 2070 \mathrm{kN} / \mathrm{m}^{2}=2629 \mathrm{kN} / \mathrm{m}^{2}$

for a mean value of $\sigma_{v}=2070 \mathrm{kN} / \mathrm{m}^{2}$.

The support designed for the pre-construction tunnel project purposes was calculated by numerical analysis using FIAC $^{3 \mathrm{D}}$ code and Rocsupport software. Table 2 summarises the types of support designed and the corresponding support pressure $\left(\mathrm{P}_{0}\right)$. During excavation significant deformations were observed in this zone and the initially designed support Type $3\left(\mathrm{P}_{0}=635 \mathrm{kN} / \mathrm{m}^{2}\right)$ had to be changed to

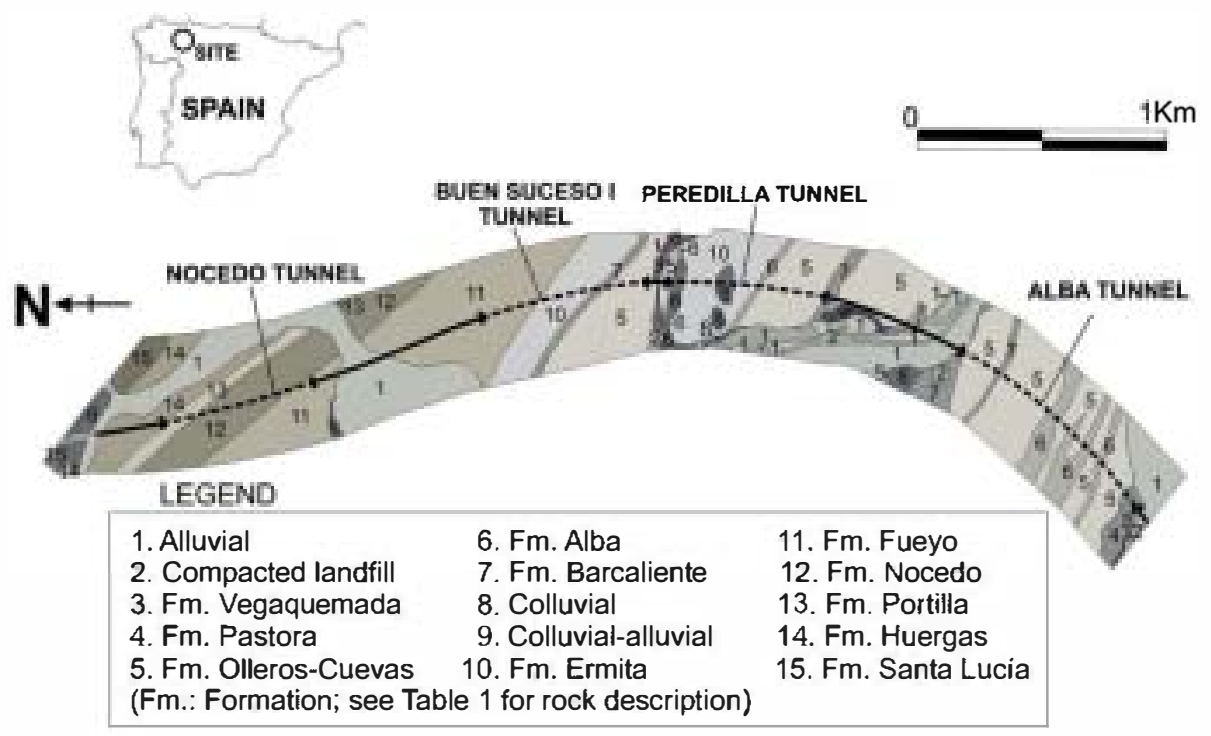

Fig. 4. Geological sketch and site locations. 


\section{BUEN SUCESO I TUNNEL}

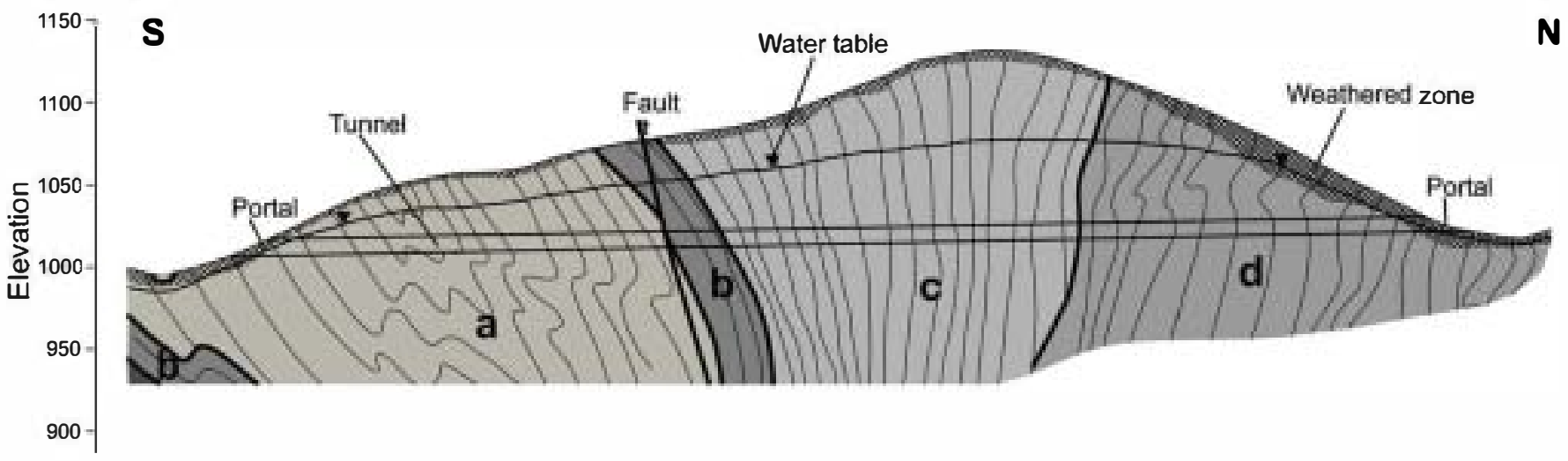

\begin{tabular}{llllllll}
\cline { 3 - 5 } Distance $(\mathrm{m})$ & 0 & 100 & 200 & 300 & 400 & 500 & 600
\end{tabular}

\begin{tabular}{|c|c|c|c|c|c|c|c|c|c|c|c|c|c|}
\hline LITHOLOGIES ${ }^{(1)}$ & \multicolumn{5}{|c|}{$\mathbf{a}$} & b & \multicolumn{4}{|c|}{ C } & & \multicolumn{2}{|l|}{ d } \\
\hline $\operatorname{RMR}^{(2)}$ & 45-2it & $45 \cdot 21$ & and & $50-23$ & 130 & \begin{tabular}{l|l|l} 
& $63-40$ & 63 \\
\end{tabular} & $33-38$ and & \multicolumn{3}{|c|}{ 63-38 } & & $55-30$ & $47-22$ \\
\hline ROCK MASS CLASS & ivi & $\begin{array}{l}\text { IV } \\
\text { (III) }\end{array}$ & $\mathrm{v}$ & $\begin{array}{l}\text { IV } \\
\text { (III) }\end{array}$ & & VIIII (II) & $\begin{array}{ll}11 \text { and } & \text { IV } \\
\end{array}$ & \multicolumn{3}{|c|}{ III and IV } & & $\begin{array}{l}\text { III } \\
\text { (IV) }\end{array}$ & YIII and IV \\
\hline SUPPORT DESIGNED ${ }^{(3)}$ & 4 & (3) & 5 & $\begin{array}{l}4 \\
\text { (3) }\end{array}$ & & $4 \mathrm{~s}^{3} 2$ & \begin{tabular}{l|l}
3 & 5
\end{tabular} & \multicolumn{3}{|c|}{3} & & 3 and 4 & $\begin{array}{l}4 \\
\text { (3) }\end{array}$ \\
\hline SUPPORT REQUIRED ${ }^{(4)}$ & $p^{4}$ & \multicolumn{2}{|l|}{5} & 4 & & 5 & & 4 & 4 & 34 & 3 & \multicolumn{2}{|r|}{5} \\
\hline TUNNEL ZONES ${ }^{(1)}$ & h & 2 & 3 & & 4 & 7 & 8 & 9 & 10 & II & & $12|n| ⿰ \mid$ & 14 \\
\hline $\begin{array}{l}\text { DIFFERENCE BETWEEN } \\
\text { SUPPORT REQUIRED } \\
\text { AND DESIGNED }\end{array}$ & 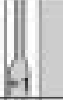 & +1 & $n$ & & +1 & $\hat{1}^{+2}$ & $+1-1$ & +1 & +1 & $f_{1}$ & & +2 & $n$ \\
\hline $\mathrm{SAF}^{(8)}$ & 135 & $1.10-1.26$ & $\begin{array}{l}1.08- \\
1.09\end{array}$ & & 1.07 & $\begin{array}{r}1.42+1.42 \\
1,1.44 \mid 1.45\end{array}$ & $\begin{array}{l}2.45 \\
45 \text { h. }\end{array}$ & $1.24 \cdot 1.32$ & $\begin{array}{l}1.23- \\
1.24\end{array}$ & $\int_{126}^{2}$ & & 1.69 - 1.84 & $1.15-2.04$ \\
\hline
\end{tabular}

(1) Lithologies: a) shales and shaly sandstones; b) shaly sandstones, shales and sandstones; c) sandstones, shales and quarzite; d) shales and shaly sandstones

(2) RMR from site investigations before construction (see Table 2)

(3) Type of Support designed from site investigations before construction (see Table 2)

(4) Type of Support required to stabilize tunnel deformation (see Table 2)

(5) Corresponding to Table 3

(6) SAF (Stress Amplification Factor)

Fig. 5. Geological profile and geomechanical characteristic of Buen Suceso I tunnel.

Type 5 (Table 2), with a $P_{f}=1760 \mathrm{kN} / \mathrm{m}^{2}$. From these results $\Delta \sigma_{\text {Hlocal }}$ was estimated: $\Delta \sigma_{\text {Hlocal }}=P_{f}-P_{0}=1760-635=1125 \mathrm{kN} / \mathrm{m}^{2}$. Once $\sigma_{\text {Hregional }}$ and $\Delta \sigma_{\text {Hlocal }}$ were obtained $\sigma_{\text {Hlocal }}, K_{\text {local }}$ and SAF was calculated:

$$
\begin{aligned}
& \sigma_{\mathrm{Hl} \bullet \mathrm{cal}}=\sigma_{\text {Hregiønal }}+\Delta \sigma_{\mathrm{Hl} \bullet \mathrm{cal}}=2629+1125=3754 \mathrm{kN} / \mathrm{m}^{2} \\
& \mathrm{~K}_{\mathrm{l} \bullet \mathrm{cal}}=\sigma_{\mathrm{Hl} \bullet \mathrm{cal}} / \sigma_{\mathrm{v}}=3754 / 2070=1.81 \\
& \mathrm{SAF}=\mathrm{K}_{\text {løcal }} / \mathrm{K}_{\text {regiønal }}=1.81 / 1.27=1.43 .
\end{aligned}
$$

\begin{tabular}{|c|c|c|c|c|}
\hline \multirow{2}{*}{$\begin{array}{l}\text { Type of } \\
\text { support and } \\
\text { RMR }\end{array}$} & \multicolumn{3}{|l|}{ Support systems } & \multirow{2}{*}{$\begin{array}{l}\text { Support } \\
\text { pressure } \\
\left(\mathrm{kN} / \mathrm{m}^{2}\right)\end{array}$} \\
\hline & Bolts & Shotcrete & Steel ribs & \\
\hline $\begin{array}{l}\text { Type } 3 \\
\text { RMR: } 40-60\end{array}$ & $\begin{array}{l}\text { Lengt } \mathrm{h}=4 \mathrm{~m} . \\
\text { Spacing } 1.5 \times 1.5 \mathrm{~m} .\end{array}$ & $\begin{array}{l}\text { Steel fibre } \\
\text { reinforced, } 12 \mathrm{~cm} \\
\text { thickness. }\end{array}$ & - & 635 \\
\hline $\begin{array}{l}\text { Type } 4 \\
\text { RMR: } 20-40\end{array}$ & $\begin{array}{l}\text { Lengt } \mathrm{h}=4 \mathrm{~m} \text {. } \\
\text { Spacing } 1 \times 1 \mathrm{~m} \text {. }\end{array}$ & $\begin{array}{l}\text { Steel fibre } \\
\text { reinforced, } 20 \mathrm{~cm} \\
\text { thickness. }\end{array}$ & $\begin{array}{l}\text { TH-29 at } \\
1 \mathrm{~m} .\end{array}$ & 1575 \\
\hline $\begin{array}{l}\text { Type } 5 \\
\text { RMR }<20\end{array}$ & - & $\begin{array}{l}\text { Steel fibre } \\
\text { reinforced, } 25 \mathrm{~cm} \\
\text { thickness. }\end{array}$ & $\begin{array}{l}\mathrm{HEB}-180 \\
\text { at } 1 \mathrm{~m} \text {. }\end{array}$ & 1760 \\
\hline
\end{tabular}

Table 2

Types of support designed of the tunnels analysed.

a For a factor of safety of 1.2 .
As the section in the Buen Suceso I tunnel was the same $\left(75 \mathrm{~m}^{2}\right)$ and the tunnel orientation was similar with respect to the geological structure, it was assumed that the deformations in this tunnel were mainly due to structural stress. An important thrust fault and lithological contact between two rock formations (sandstones and shales) with significantly contrasted strength properties were identified in this zone. The same procedure was applied to the other zones affected by deformations in the four tunnels analysed. Table 3 presents the main results.

The deformations observed in these tunnel zones have been attributed to the following geological and geomechanical factors:

- Thrust faults were identified in zones with significant deformations with SAF values ranging from 1.07 to 2.00. No relationship was found between fault thickness and SAF.

- Synclinal folds dipping between $55^{\circ}-60^{\circ}$ were also identified in relation to high deformations tunnel zones. SAF values in these zones ranged from 1.10 to 1.26 .

- Lithological contacts between rocks with different geomechanical behaviour were also associated with significant deformations. SAF values in zones with contacts between limestones and shales ranged from 2.22 to 2.90 and between sandstones and weathered shales ranged from 1.42 to 1.83 .

- In tunnel zones with low overburden thickness, SAF values ranged from 1.15 to 2.04. In these cases the overburden thickness was less than $35 \mathrm{~m}$. 
Table 3

Tunnel's zones affected by significant deformations.

\begin{tabular}{|c|c|c|c|c|c|c|}
\hline \multirow[t]{2}{*}{ Tunnel } & \multirow{2}{*}{$\begin{array}{l}\text { Tunnel } \\
\text { zones }\end{array}$} & \multicolumn{2}{|l|}{ Support } & \multirow{2}{*}{$\begin{array}{l}\text { Load pressure } \\
\text { differences }\left(\mathrm{kN} / \mathrm{m}^{2}\right)\end{array}$} & \multirow[t]{2}{*}{ Geological anisotropies } & \multirow{2}{*}{$\begin{array}{l}\text { SAF } \\
\left(\mathrm{K}_{\text {loccal }} / \mathrm{K}_{\text {regional }}\right)\end{array}$} \\
\hline & & $\begin{array}{l}\text { Designed } \mathrm{P}_{\bullet} \\
\left(\mathrm{kN} / \mathrm{m}^{2}\right)\end{array}$ & $\begin{array}{l}\text { Required } P_{f} \\
\left(k N / m^{2}\right)\end{array}$ & & & \\
\hline \multirow[t]{14}{*}{ Buen Suceso I } & 1 & $\begin{array}{l}\text { Type } 4 \\
P_{\bullet}=1575\end{array}$ & $\begin{array}{l}\text { Type } 5 \\
P_{f}=1760\end{array}$ & +185 & Not identified & $154-2.09$ \\
\hline & 2 & $\begin{array}{l}\text { Type } 4 \\
\mathrm{P}_{\bullet}=1575\end{array}$ & $\begin{array}{l}\text { Type } 5 \\
P_{f}=1760\end{array}$ & +185 & Synclinal fold & $1.10-1.26$ \\
\hline & 3 & $\begin{array}{l}\text { Type } 4 \\
\mathrm{P}_{\mathbf{0}}=1575\end{array}$ & $\begin{array}{l}\text { Type } 5 \\
P_{f}=1760\end{array}$ & +185 & Folds + lithological anisotropies & $1.08-1.09$ \\
\hline & 4 & $\begin{array}{l}\text { Type } 4 \\
P_{\bullet}=1575\end{array}$ & $\begin{array}{l}\text { Type } 5 \\
P_{f}=1760\end{array}$ & +185 & Fault & $1.07-1.08$ \\
\hline & 5 & $\begin{array}{l}\text { Type } 4 \\
\mathrm{P}_{\mathbf{0}}=1575\end{array}$ & $\begin{array}{l}\text { Type } 5 \\
P_{f}=1760\end{array}$ & +185 & Fault & 1.07 \\
\hline & 6 & $\begin{array}{l}\text { Type } 3 \\
\mathrm{P}_{0}=635\end{array}$ & $\begin{array}{l}\text { Type } 5 \\
P_{f}=1760\end{array}$ & +1125 & Fault & $1.42-1.44$ \\
\hline & 7 & $\begin{array}{l}\text { Type } 3 \\
P_{\bullet}=635\end{array}$ & $\begin{array}{l}\text { Type } 5 \\
P_{f}=1760\end{array}$ & +1125 & Lithological anisotropies & $1.42-1.45$ \\
\hline & 8 & $\begin{array}{l}\text { Type } 3 \\
P_{\bullet}=635\end{array}$ & $\begin{array}{l}\text { Type } 4 \\
P_{f}=1575\end{array}$ & +940 & Not identified & $133-135$ \\
\hline & 9 & $\begin{array}{l}\text { Type } 3 \\
P_{\bullet}=635\end{array}$ & $\begin{array}{l}\text { Type } 4 \\
P_{f}=1575\end{array}$ & +940 & Not identified & $1.24-132$ \\
\hline & 10 & $\begin{array}{l}\text { Type } 3 \\
P_{\bullet}=635\end{array}$ & $\begin{array}{l}\text { Type } 4 \\
P_{f}=1575\end{array}$ & +940 & Not identified & $1.23-1.24$ \\
\hline & 11 & $\begin{array}{l}\text { Type } 3 \\
P_{\bullet}=635\end{array}$ & $\begin{array}{l}\text { Type } 4 \\
P_{f}=1575\end{array}$ & +940 & Not identified & 1.26 \\
\hline & 12 & $\begin{array}{l}\text { Type } 3 \\
P_{\bullet}=635\end{array}$ & $\begin{array}{l}\text { Type } 5 \\
P_{\mathrm{f}}=1760\end{array}$ & +1125 & Important lithological anisotropies & $1.55-1.69$ \\
\hline & 13 & $\begin{array}{l}\text { Type } 3 \\
P_{\bullet}=635\end{array}$ & $\begin{array}{l}\text { Type } 5 \\
P_{\mathrm{f}}=1760\end{array}$ & +1125 & Important lithological anisotropies & $1.64-1.83$ \\
\hline & 14 & $\begin{array}{l}\text { Type } 4 \\
P_{\bullet}=1575\end{array}$ & $\begin{array}{l}\text { Type } 5 \\
\mathrm{P}_{\mathrm{f}}=1760\end{array}$ & +185 & Low overburden thickness & $1.15-2.04$ \\
\hline \multirow[t]{7}{*}{ Peredilla } & 1 & $\begin{array}{l}\text { Type } 3 \\
\mathrm{P}_{\mathbf{0}}=635\end{array}$ & $\begin{array}{l}\text { Type } 4 \\
P_{\mathrm{f}}=1575\end{array}$ & +940 & Fault and highly fractured rocks & $157-1.62$ \\
\hline & 2 & $\begin{array}{l}\text { Type } 3 \\
P_{\bullet}=635\end{array}$ & $\begin{array}{l}\text { Type } 5 \\
P_{f}=1760\end{array}$ & +1125 & Fault and highly fractured rocks & $1.62-1.68$ \\
\hline & 3 & $\begin{array}{l}\text { Type } 3 \\
P_{\bullet}=635\end{array}$ & $\begin{array}{l}\text { Type } 4 \\
P_{f}=1575\end{array}$ & +940 & Fault and highly fractured rocks & $1.49-1.51$ \\
\hline & 4 & $\begin{array}{l}\text { Type } 3 \\
P_{\bullet}=635\end{array}$ & $\begin{array}{l}\text { Type } 4 \\
P_{f}=1575\end{array}$ & +940 & Not identified & $133-139$ \\
\hline & 5 & $\begin{array}{l}\text { Type } 3 \\
P_{\bullet}=635\end{array}$ & $\begin{array}{l}\text { Type } 5 \\
P_{f}=1760\end{array}$ & +1125 & Not identified & $1.51-1.54$ \\
\hline & 6 & $\begin{array}{l}\text { Type } 3 \\
P_{\bullet}=635\end{array}$ & $\begin{array}{l}\text { Type } 4 \\
P_{f}=1575\end{array}$ & +940 & Not identified & $1.45-1.46$ \\
\hline & 7 & $\begin{array}{l}\text { Type } 3 \\
\mathrm{P}_{\mathbf{0}}=635\end{array}$ & $\begin{array}{l}\text { Type } 5 \\
P_{f}=1760\end{array}$ & +1125 & Low overburden thickness & $5.07-11.86$ \\
\hline \multirow[t]{9}{*}{ Nocedo } & 1 & $\begin{array}{l}\text { Type } 3 \\
\mathrm{P}_{\mathbf{0}}=635\end{array}$ & $\begin{array}{l}\text { Type } 5 \\
P_{f}=1760\end{array}$ & +1125 & Not identified & $134-1.44$ \\
\hline & 2 & $\begin{array}{l}\text { Type } 3 \\
P_{0}=635\end{array}$ & $\begin{array}{l}\text { Type } 4 \\
P_{\mathrm{f}}=1575\end{array}$ & +940 & Fault & $1.28-1.29$ \\
\hline & 3 & $\begin{array}{l}\text { Type } 3 \\
P_{\bullet}=635\end{array}$ & $\begin{array}{l}\text { Type } 4 \\
P_{\mathrm{f}}=1575\end{array}$ & +940 & Fault and lithological anisotropies & 1.23 \\
\hline & 4 & $\begin{array}{l}\text { Type } 3 \\
P_{\bullet}=635\end{array}$ & $\begin{array}{l}\text { Type } 4 \\
P_{\mathrm{f}}=1575\end{array}$ & +940 & Fault and lithological anisotropies & 1.24 \\
\hline & 5 & $\begin{array}{l}\text { Type } 3 \\
P_{\bullet}=635\end{array}$ & $\begin{array}{l}\text { Type } 4 \\
P_{\mathrm{f}}=1575\end{array}$ & +940 & Not identified & $132-135$ \\
\hline & 6 & $\begin{array}{l}\text { Type } 3 \\
P_{\bullet}=635\end{array}$ & $\begin{array}{l}\text { Type } 4 \\
P_{\mathrm{f}}=1575\end{array}$ & +940 & Fault & 1.86 \\
\hline & 7 & $\begin{array}{l}\text { Type } 3 \\
\mathrm{P}_{\mathbf{0}}=635\end{array}$ & $\begin{array}{l}\text { Type } 4 \\
P_{\mathrm{f}}=1575\end{array}$ & +940 & Fault & 2.00 \\
\hline & 8 & $\begin{array}{l}\text { Type } 3 \\
P_{\bullet}=635\end{array}$ & $\begin{array}{l}\text { Type } 5 \\
P_{f}=1760\end{array}$ & +1125 & Important lithological anisotropies & $2.22-2.90$ \\
\hline & 9 & $\begin{array}{l}\text { Type } 3 \\
P_{0}=635\end{array}$ & $\begin{array}{l}\text { Type } 5 \\
P_{\mathbf{f}}=1760\end{array}$ & +1125 & Low overburden thickness and fault & $2.90-3.21$ \\
\hline \multirow[t]{6}{*}{ Alba } & 1 & $\begin{array}{l}\text { Type } 4 \\
P_{\bullet}=1575\end{array}$ & $\begin{array}{l}\text { Type } 5 \\
P_{f}=1760\end{array}$ & +185 & Low overburden thickness & $137-138$ \\
\hline & 2 & $\begin{array}{l}\text { Type } 4 \\
P_{\bullet}=1575\end{array}$ & $\begin{array}{l}\text { Type } 5 \\
P_{f}=1760\end{array}$ & +185 & Low overburden thickness & 136 \\
\hline & 3 & $\begin{array}{l}\text { Type } 4 \\
P_{\bullet}=1575\end{array}$ & $\begin{array}{l}\text { Type } 5 \\
P_{f}=1760\end{array}$ & +185 & Low overburden thickness & $133-134$ \\
\hline & 4 & $\begin{array}{l}\text { Type } 4 \\
P_{\bullet}=1575\end{array}$ & $\begin{array}{l}\text { Type } 5 \\
P_{f}=1760\end{array}$ & +185 & Low overburden thickness and highly fractured rocks & $1.26-133$ \\
\hline & 5 & $\begin{array}{l}\text { Type } 4 \\
P_{\bullet}=1575\end{array}$ & $\begin{array}{l}\text { Type } 5 \\
P_{\mathrm{f}}=1760\end{array}$ & +185 & Low overburden thickness and highly fractured rocks & $1.24-1.26$ \\
\hline & 6 & $\begin{array}{l}\text { Type } 4 \\
P_{\bullet}=1575\end{array}$ & $\begin{array}{l}\text { Type } 5 \\
P_{f}=1760\end{array}$ & +185 & Low overburden thickness and highly fractured rocks & $1.16-1.23$ \\
\hline
\end{tabular}


Table 3 (continued)

\begin{tabular}{|c|c|c|c|c|c|c|}
\hline \multirow[t]{2}{*}{ Tunnel } & \multirow{2}{*}{$\begin{array}{l}\text { Tunnel } \\
\text { zones }\end{array}$} & \multicolumn{2}{|l|}{ Support } & \multirow{2}{*}{$\begin{array}{l}\text { Load pressure } \\
\text { differences }\left(\mathrm{kN} / \mathrm{m}^{2}\right)\end{array}$} & \multirow[t]{2}{*}{ Geological anisotropies } & \multirow{2}{*}{$\begin{array}{l}\text { SAF } \\
\left(\mathrm{K}_{\text {local }} / \mathrm{K}_{\text {regional }}\right)\end{array}$} \\
\hline & & $\begin{array}{l}\text { Designed } \mathrm{P}_{\bullet} \\
\left(\mathrm{kN} / \mathrm{m}^{2}\right)\end{array}$ & $\begin{array}{l}\text { Required } P_{f} \\
\left(\mathrm{kN} / \mathrm{m}^{2}\right)\end{array}$ & & & \\
\hline & 7 & $\begin{array}{l}\text { Type } 4 \\
P_{\bullet}=1575\end{array}$ & $\begin{array}{l}\text { Type } 5 \\
P_{f}=1760\end{array}$ & +185 & Low overburden thickness and highly fractured rocks & $1.15-1.16$ \\
\hline & 8 & $\begin{array}{l}\text { Type } 4 \\
P_{\bullet}=1575\end{array}$ & $\begin{array}{l}\text { Type } 5 \\
P_{f}=1760\end{array}$ & +185 & Intense folding and fault & $1.09-1.10$ \\
\hline & 9 & $\begin{array}{l}\text { Type } 3 \\
\mathrm{P}_{\bullet}=635\end{array}$ & $\begin{array}{l}\text { Type } 5 \\
P_{f}=1760\end{array}$ & +1125 & & $1.55-1.56$ \\
\hline & 10 & $\begin{array}{l}\text { Type } 3 \\
P_{\bullet}=635\end{array}$ & $\begin{array}{l}\text { Type } 4 \\
P_{f}=1575\end{array}$ & +940 & & $1.40-1.44$ \\
\hline
\end{tabular}

- Some tunnels were also affected by several factors acting in combination. The following SAF values were obtained in these cases:

- Thrust faults and folds: 1.09 to 1.56

- Thrust faults and geomechanical anisotropies: 1.23 to 1.68

- Folds and geomechanical anisotropies: 1.09

- Low overburden thickness and faults: 2.90 to 3.21

- Low overburden thickness and geomechanical anisotropies: $1.15-1.33$

- In $25 \%$ of the tunnel zones no specific relationship was found between geological anisotropies and tunnel deformations.

Fig. 6 shows different SAFvaluesrelated to the geological anisotropies identified in the tunnel zones. The mean SAF values range from 1.1 to 2.5 The highest values correspond to geomechanical anisotropies and faults.

\section{Discussion and conclusions}

This paper presents a methodological procedure for estimating insitu stress in a rock mass tunnel excavation affected by relevant geological and geomechanical anisotropies. This procedure is based on first, identifying the zones in the tunnel with geological structures and other anisotropies which give rise to structural stress and then, measuring the deformations occurring during the tunnel excavation, that required increased support over and above those initially envisaged in the project.

From the pressure exerted by the support in the excavation to stabilise the deformations, the in-situ stress increment over the mean regional stress values ( $\left.K_{\text {regional }}\right)$ was calculated. Based on these results, the in-situ stress in each significant zone of the tunnel $\left(\mathbf{K}_{\text {local }}\right)$ was assessed. The in-situ regional stress was estmated using hydrofracture tests and by applying the TSI index. The increase of in-situ stress is expressed by the relationship $\mathrm{K}_{\text {local }} / \mathrm{K}_{\text {regional, }}$ defined by the SAF.

The results below were obtained from the analysis of forty specific significant zones in four tunnels where greater deformations occurred than had been envisaged in the project:

- Geological structures and other anisotropies were identified in the rock mass, consisting of faults and areas of high tectonic fracturing, folds with steeply dipping flanks and contacts between lithological formations with different geomechanical properties.

- The SAF values obtained in the forty specified zones ranged from 1.1 to 2.5 and the local factors analysed show the following characteris intervals:

- Thrust fault zones: $1.3-1.7$

- Folds with steeply dipping flanks : 1.1-1.3

- Geomechanical anisotropic zones: 1.4-2.5

- Low overburden thickness zones: 1.1-1.4.

Given that in the tunnels analysed the sections are the same and the orientation is also similar relative to the direction of the in-situ stresses, the structural stresses are considered to be the main cause of the deformations and therefore of the increment in the in-situ stress.

The main conclusions highlight the following practical aspects of tunnel design:

- The importance of evaluating the state of stress of the rock mass where a tunnel is designed.

- The influence of geological structures originated by high compressive tectonic stress regimes and other rock mass anisotropies on the design of support and control of deformations.

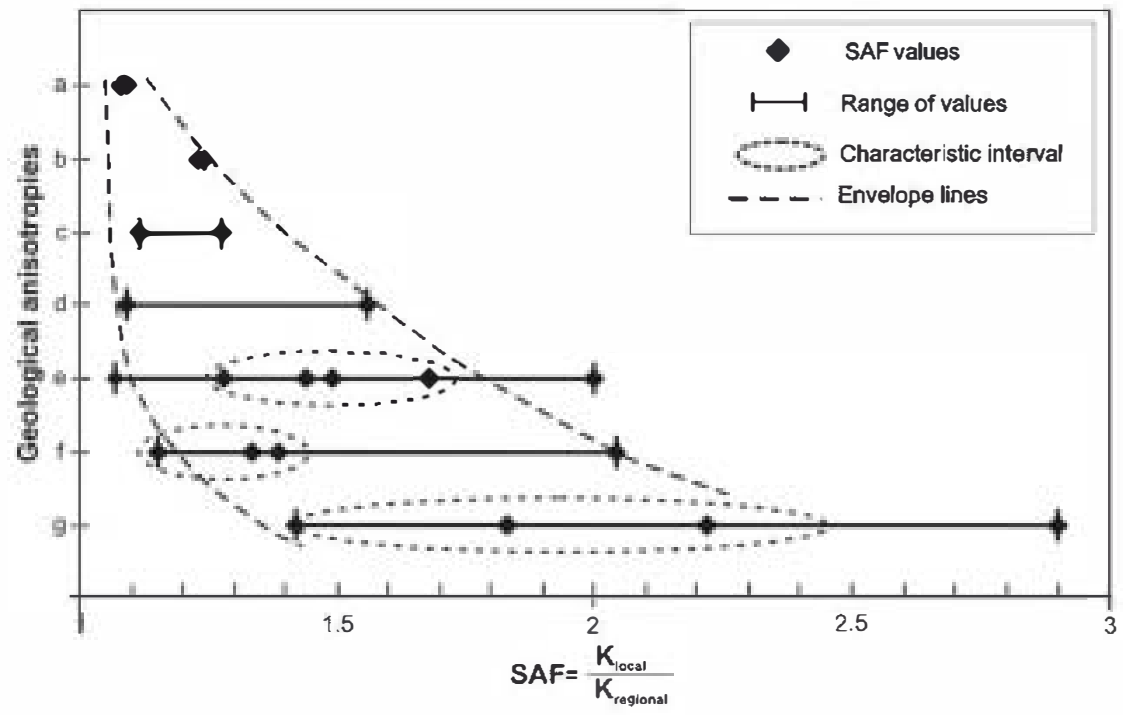

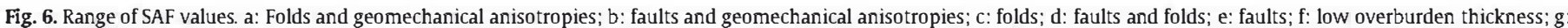
geomechanical anisotropies. 
- The possibility that within a single rock mass in-situ stress may occur which significantly exceeds the mean regional values and that where the orientation of these stresses is unfavourable to the excavation, the increments due to structural stresses would be even greater than the estimated values obtained in the Pajares tunnels, where the orientation was always favourable.

- The methodology described may be applied to other rock masses affected by similar geological anisorropies to those studied here. allowing geomechanical zoning to be carried out along the geological profile of the tunnel, to identify potential stress amplification zones and provide useful criteria for tunnel design.

\section{Acknowledgements}

The authors would like to thank ADIF, and in particular Raúl Miguez, for the facilities provided which allowed them to use data from the Pajares tunnels. They are very grateful to Dr. Mercedes Ferrer of the Instituto Geológico y Minero de España for reviewing the manuscript.

\section{References}

Bott, M.H.P., Kusznir, N.J., 1984. The origin oftectonic stress in the lithosphere. Tectonophysies 105, 1-13.

Bulin, N.K., 1971. The present stress field in the upper parts of the crust. Geotectonics 3 , 133-139.

Coates, D.F., Grant, F., 1966. Stress measurements at Elliot Iake. Can. Min. Metall. Bull. 59 (649), 603-613.

Cornet, F.H., Burlet, D., 1992. Stress field determinations in France by hydraulic test in boreholes. J. Geophys. Res. 97 (B8), 11.829-11.849.

Evans, K.F., Oertel, G., Engelder, T., 1989. Appalachian stress study: 2. Analysis of Devonian shale core: some implications for the nature of contemporary stress variations and Alleghanian deformation in Devonian rocks. J. Geophys. Res. 94 (B6), 7155-7170.

González de Vallejo, Ll., Hijazo, T., 2008. A new method of estimating the ratio between in-situ rock stresses and tectonics based on empirical and probabilisticanalyses. Eng. Geol. 101, 185-194.

Goodman, RE, 1980. Introduction to Rock Mechanics. John Wiley and Sons, New York $478 \mathrm{pp}$.

Griggs, D.T., Turner, F.J., Heard, H.C., 1960 . Deformation of rocks at $500^{\circ}$ to $800^{\circ} \mathrm{C}$. Rock Deformation: Geol. Soc. Am. Mem., 79, pp. 39-104

Gunzburger, Y., Cornet, F.H., 2007. Rheological characterization of a sedimentary formation from a stress profile inversion. Geophys. J. Int. 168, 402-418.

Hast, N., 1967. The state of stresses in the upper part of the Earth's crust. Eng. Geol. 2 (1), 5-17 release of the World Stress Map. (available online at www.world-stress-map.org). Hijazo, T., 2009. Estimación de las tensiones naturales y su aplicación aldiseño de túneles. PhD Thesis (UCM). Madrid: E-prints Complutense (http://eprints.ucmes/10836/).

Hoek, E., Brown, E. T., 1980. Underground excavations in rock. Inst. of Mining and Metallurgy (Ed.), London. $527 \mathrm{pp}$.

Hoek, E., Marinos, P.G., 2009. Tunnelling in overstressed rock. In: Vrkljan, I. (Ed.), Rock Engineering in Difficult Ground Conditions-Soft Rocks and Karst. : ISRM Regional Symposium EUROCK 2009, Croacia. Taylor and Francis Group, pp. 49-72.

Hudson, JA., Harrison, J.P., 2005. Engineering rock mechanics: an introduction to the principles. Elsevier (Ed) (4th edition), $444 \mathrm{pp.}$

Hullera Vasoo-Leonesa, S.A., 1988. Estudio geotécnico e hidrogeológico para los pozos de la nueva mina. $211 \mathrm{pp}$. Unpublished

Lavrov, A. 2003. The Kaiser effect in rocks: principles and stress estimation techniques. Int. J. Rock Mech. Min. Sci. 40, 151-171.

Lehtonen, A., Cosgrove, J.W., Hudson, JA, Johansson, E., 2012. An examination of in-situ rock stress estimation using the Kaiser effect. Eng. Geol. 124, 24-37.

Miguez, R., 2005. Túneles de Pajares. Adif (Ed.), Madrid. 612 pp.

Montoto, M., Hardy, H.R., 1991. Kaiser effect in intact rock: current status as a feasible means of evaluating thermal and mechanical loading. 7th International Congress on Rock Mechanics, Aachen/Deutschland, pp. 569-572.

Savage, W.Z., Swolfs, H.S., Amadei, B., 1992. On the state of stress in the near surface of the earth's crust. Pure Appl. Geophys. 138, 207-228.

Special issue of the IJRMMS: rock stress estimation ISRM suggested methods and associated supporting papers, 2003. In: Cornet, F.H. (Ed.), Int. J. Rock Mech. Min. Sci., 40. 7-8, pp. 955-1276.

Stephansson, O., 1993. Rock stress in the Fennoscandian shield In: Hudson, J.A. (Ed.) Comprehensive Rock Engineering, vol. 3. Pergamon Press, Oxford, pp. 445-459. chapter 17 .

U.T.E. Geoconsult-Ineco-CGS, 2003. Proyecto básico de los túneles de Pajares. Inédito. Unpublished manuscript.

U.T.E. Ineco-Geoconsult, 2005. Proyecto de construcción de plataforma línea de alta velocidad León-Asturias. La Robla-Pola de Lena (Variante de Pajares), ramo: La Robla-Túneles de Pajares. Unpublished manuscript.

Villaescusa, E., Windsor, C.R., Li, J., Baird, G., Seto, M., 2003. Experimental verification of AE in-situ stress measurements. Proceedings of the 3th International Symposium on Rock Stress RS Kumamoto, Kumamoto, Japan, pp. 395-402.

Voight, B., 1966. Beziehung zwischen grossen horizontalen spannungen im Gebirge und der tektonik und der Abtragung. Proc. 1st Cong. Int. Soc. Rock Mech. (ISRM) lisbon, LNEC, Lisbon, vol II, pp. 51-56.

Zang, A., Stephansson, O., 2010. Stress field of the Earth's crust. Springer. $322 \mathrm{pp}$.

Zoback, M.D., Tsukahara, H., Hickman, S., 1980. Stress measurements at depth in the vicinity of the San Andreas fault: implications for the magnitude of shear stress at depth. J. Geophys. Res. 85 (B11), 6.157-6.173.

Zoback, M.L, Zoback, M.D., Adams, J., Assumpcão, M., Bell, S., Bergman, E.A., Blümling P., Brereton, N.R., Denham, D., Ding, J., Fuchs, K., Gay, N., Gregersen, S., Gupta H.K., Gvishiani, A., Jacob, K., Klein, R., Knoll, P., Magee, M., Mercier, J.L, Müiller, B.C., Paquin, C., Rajendran, K., Stephansson, O., Suarez, G., Suter, M., Udias, A., Xu, Z.H., Zhizhin, M., 1989. Global patterns of tectonic stress. Nature 341, 291-298. 